Ahmadova M. I.,

\title{
MONO AND POLY INTENSIVE FEATURES OF THE INTERROGATIVE ACT OF DIRECT SPEECH IN ENGLISH AND AZERBAIJANI
}

\begin{abstract}
Summary. Modern linguistics is actively working on ways to optimize interpersonal communication. This problem has been on the agenda at almost all times, but its broad scientific and theoretical study is associated with modern linguistics. This problem is characterized by the use of language in the communication process, finding more appropriate ways to convey the author's intention. Because accurate, fluent expression of thought is one of the features of optimal speech. In this sense, the topic of the article is actual. The article is devoted to the mono and poly intensiveness of interrogative direct speech acts in the English and Azerbaijani languages. The purposeful arrangement of utterances based on certain rules in a communication situation in society is called a "speech act". The main position of the act of speech is to influence the listener. In this context, the act of speech, sentence, and utterance, depending on the communicative need of language units, can be reworked by the author or speaker to give a new communicative tone or meaning to the existing form. The creative approach to the opinions of prominent experts such as Deirdre Wilson, Dan Sperber, John Searle, Russel Conrad, John Austin, Irina Vladimirovna Arnold the problems of formation of question-based direct speech act are explained. When speaking of a question-based indirect speech act in English and Azerbaijani, it is divided into mono and poly intensive types. Mono intensiveness refers to the construction of a sentence on one semantic idea in indirect speech. Poly intensive direct speech is characterized by the presentation of two or three ideas in one structure. Successful communication in our speech ensures our mutual understanding and covers a very high percentage of our speech activity. The article analyzes the main features of the interrogative direct speech act and its communicative function based on facts of both-
\end{abstract}

English and Azerbaijani languages. As a result, the article concludes that the functional meanings of the interrogative sentences in the text are rich.

Key words: text, question, processing, direct speech act, sentence, utterance, mono intentionality, poly intentionality.

A speech act is a speech activity performed by utterances, and it is expressed by different types of sentences. As we know, a sentence is the smallest unit of communication. Adequate use of language resources in the process of communication depends on the intellectual level of the language carrier. For example, the question sentences in the language acquire a new tone, moving away from the formal content, depending on the purpose of communication, and the weakening of the relationship with the question content in such sentences is accompanied by the formation of direct speech in the language. D. Wilson, D. Sperber divides the question sentences involved in the role of the direct speech act in English into the following types.
1. Rhetorical questions. (Did you want to give up smoking?)

2. Test questions. (What is a solar battery?)

3.Guess questions. (Which hand is it in?)

4.Surprise questions. (-The president has resigned - Has he?)

5.Expository-questions. (How are non-declarative sentences understood?)

6. Self-addressed questions. (Now why did I say that?)

7. Speculative questions. (What is the best explanation of interrogative sentences?)

8. Echoic-questions. (John sighed, "Would she never speak") $[1$, p. 151].

The main task of the act of speech is to influence the listener to the opposite side. To get to the heart of the matter, let's look at the terms of a sentence, an utterance, and an act of speech. A sentence is a multifaceted phenomenon formed based on the interaction of language units. Linguists emphasize its three aspects: formal, intellectual, and communicative. From a communicative point of view, it is a sentence. In this regard, in communication, the sentence is an independent communicative unit, it has an intonation form in oral speech. It may even have the status of an actual member [2]. At the same time, the sentence has a model and structure. It can be considered as a sentence when it is located in the text. A sentence is an integral part of a text, as opposed to a sentence.

The purposeful arrangement of utterances based on certain rules in a communication situation in society is called a "speech act". In terms of communication, it consists of illocutive and perlocution parts. The act of speech is directed towards a goal by the speaker; manifests itself as an act of influencing the listener. The speech act is a dynamic phenomenon. It is systematically connected with the communicative parameter of speech. Although speech and speech acts have different linguistic meanings, they intersect in the context of speech acts. Because if a speech is an instrument, the act of speech is the functional activity of that instrument. Functional activity is already associated with the act of speech. Every utterance has an assertion; it consists of either affirmation or negation of the thoughts in the speech. As a result, it exists as the general content of the sentence proposition in the context of affirmation and negation. The illocutive part of the speech act is related to the author's intention. In this case, the author gives his intention in the text, either openly or covertly. If he presents an event in the form of a text, it means that he gives his ideas in the background of that event. Depending on the speaker's speech strategy, an interrogative direct speech act is used [3, p. 356]. In this case, the purpose is to achieve the goal set by the speaker or 
writer. The author asks a question, and the listener must answer it in the form of a "yes" or "no" position. For example: "Can you sing that song again?" It is known that the proposition of a direct speech act in the form of a question (I want you to sing that song again) is answered in an assertive context. The need to use the act of direct speech in the form of a question is related to the continuation of the scenario in a new direction of development.

The act of speech is the main object of pragma linguistics. Austin, Searle, Halliday, and others are the founders of this theory. According to this theory, the minimum unit of communication is a statement, question, order, description, request, explanation, congratulation, and so on. The development of these acts in speech depends on the intensity of the author. According to Austin's theory, the act of speech consists of three stages:

1.The communicative purpose of the speaker.

2.Derivatives of speech, its phonetic and grammatical form. This stage expresses the relationship between thought and reference.

3. Influence on the addressee [4, p. 22-30].

Searle, on the other hand, identifies the types of illocutive speech by distinguishing between proposition and illusion [5, p. 170-194]. I.V. Arnold calls them rhetorical questions with emphatic confirmation when speaking about the interrogative direct speech act [6, p. 165].

When speaking of an interrogative direct speech act in English, it is divided into mono and poly intensive types. Mono intendancy serves only one intention. This type of direct action of speech moves away from the content of the question, which is almost formally similar. Let's look at examples of English and Azerbaijani languages:

I. Mono intentional act of direct speech:1). Do you mind posting this letter? 2). Will you say I am out? [7, p. 141-153].

In the above-mentioned examples, the question form expresses the external side of the act of direct speech, but its main content consists of the semantics of the request. It is a textual situation that creates it. The request does not come from a modal verb (will) here, but a homonymous form. Mono intention loses its connection with formally similar questions. In modern English, these forms lose their connection with the illocutive meaning and become an indirect act of speech. In modern English, a similar form (question) does not have that illocutive power.

In modern Azerbaijani, the tone of the request plays a leading role in sentences such as "Siz o kitabı mənə verə bilərsinizmi?": ("Xahiş edirəm o kitabı mənə verin"). Such direct acts of speech, both in English and in Azerbaijani, are based almost exclusively on the meaning of the request. We have noted above that in this context, the content of the question, which has similar forms, weakens in the act of direct speech, the propositional meaning strengthens and plays a leading role. For example:

"Dance fished in her blue Coach purse for her ID card, not reacting as she saw a tiny toy bat, from last year's Halloween, that either twelve-year-old Wes, his younger sister, Maggie, or possibly both conspirators had slipped into the bag that morning as a practical joke. She thought: How's this for a contrasting life? An hour ago she was having breakfast with her children in the kitchen of their homey Victorian house in idyllic Pacific Grove, two exuberant dogs at their feet begging for bacon, and now here she sat, across a very different table from a convicted murderer [8] Isn't life full of contrasts? Although is not said with interrogative intonation, the direct answer is not demanded. On the other hand, the question intonation of the mentioned sentence also has a small tone. In the context of the text, this tone does not completely override the general question cover of the sentence, but it takes the sentence away from the content of the question.

In Azerbaijani:

“- Kim deyəcək? Xudayar bəyin arvadı özü deyir.Mən elə ora getmişdim. Getdim ki, görüm bəlkə hələ Xudayar şəhərə getmiyibdi, bəlkə eşşəyin alam gətirəm.Xudayar bəy çoxdan qoyub gedib.Arvad özü mənə dedi.Mən hələ heç soruşmadım eşşəyi nədən ötrü Xudayar bəy aparıb şəhərə.A kişi, hələ arvad məni bir aləm məzəmmət eleyib ey!Mənə deyir ki, siz məgər malınızdan keçmisiniz? Siz bilmirdiniz ki, Xudayar bəy eşşəyini nədən ötrü apardı şəhərə? Apardı Heydərxan körpüsündən ötrü sal daşısınlar. Mənə bərk-bərk tapşırdı ki, Әhmədi yolluyaq eşşəyi alıb gətirsin" $[9$, p. 90].

In the given examples "Kim deyəcək?", "Mənə deyir ki, siz məgər malınızdan keçmisiniz? Siz bilmirdiniz ki, Xudayar bəy eşşəyini nədən ötrü apardı şəhərə?” the interrogative direct speech act is determined according to the speech situation; It is also possible to draw a mental conclusion on the basis of that situation. These indirect speech acts are pragmatically mono intensive. The proposition of the first example is "no one will say", the meaning of the second is "I have not given my property to anybody", and the meaning of the third is "You knew the purpose of Khudayar bey's taking the donkey to the city". In fact, the question layer is the external side of the meaning of the given sentences in the text, their pragmatics is defined in the "deep layer", and the top layer is formed as a result of the development of the existing question intonation in the language.

II. The act of poly intensive indirect speech. These types of indirect speech acts cover not one, but several pragmatic meanings. When speaking of an act of poly intensive indirect speech, A.Q. Pospelova classifies it as follows:

1. The features of the modeling of the actual speech act are fully covered. Why not to leave her alone?

2. In this model, the formal pragmatic meaning of the act of direct speech is accompanied by the actual pragmatic meaning. May I tell you that you are absolutely wrong?

3. The act of speech without implicit means. In this category they are associated with a high level of context. What do you want in here?

In this example, "to go" is used in a situational sense, and this model is often referred to in speech by the principle of the economy [7, p. 143]. There are two approaches to the issue when talking about the pragmatic features of the act of direct speech in the context of the text:

1. The role of interrogative direct speech in textual pragmatics in the context of the text. 2. The general meaning is expressed by the act of direct speech (question-based). Both aspects are closely related. If in the first case the communicative aspect comes to the fore, in the second the general pragmatic meaning, which includes the propositional meaning of the act of direct speech, plays a leading role. Unlike mono intensive, poly intensive direct speech has an additional accompanying meaning in addition to the leading pragmatic meaning. This is due to communication conditions and communicative needs. Let us consider the general meaning of the above-mentioned interrogative act of direct speech in the context of poly intensiveness:

1. Surprise-question; What the hell had I done? Why had I come to this awful country? I was going to hate it. I already knew. There 
was no way I could possibly get used to any of this. And now I was stuck here (What the hell had I done? Why had I come to this awful country? I was going to hate it. I already knew. There was no way I could possibly get used to any of this. And now I was stuck here [7].

In the direct speech mentioned in the example of the English language, the proposition is not unequivocally limited to a general pragmatic meaning (ie, "surprise"), besides, there are "question shades" in that context.

Let's look at a similar fact in the Azerbaijani language:

Qəribə idi. Axı ona nə olmuşdu? Nə üçün İmranın səsini, ayaq tappiltısını eşidəndə yuxusu qaçırdı? İmran ki, hələ ona toxunan bir söz deməmişdi, bircə dəfə onu narahat etməmişdi. Bəs səbəb nə idi ki, əvvəllər Tükəzban xala ilə birlikdə sakitcə yaşayan Nərgiz İmran gələndən sonra özünü narahat hiss edirdi? [10, p. 39]. In this example, too, "Axı ona nə olmuşdu? Nə üçün İmranın səsini, ayaq tappiltısını eşidəndə yuxusu qaçırdı?" (What happened to him? Why could he not fall asleep when he heard Imran's voice and footsteps? There is an analogical pragmatic meaning. As can be seen, poly intensiveness presents itself as a communicative need.

2. Address-surprise; "Liz? Why won't you kiss me?" [11]. In this example, "Liz?" is a remark, even if it exists as a surprise, an appeal, an emotion, or a faint tone. Such poly intensiveness can be observed in the examples of the Azerbaijani language:

"Azər? Sən bunun səbəbini bilmirsən?" The above-mentioned direct acts of speech are widely used in the Azerbaijani language.

3. Objection; "Shall I get more drinks?" said Paul, with a cough. "What do you...? Urn... how about the same again? I'll get that, then" [11].

Bu zaman no Allah qonağı, ay kişi? [10, p. 123] In the above examples, the note of objection sometimes rises to the semantics of denial.

4. Protest-Denial; "So? So what? You happened to meet me through James. So what?" [11].

5. Emotional confirmation; "Why not?" said Liz, giving me a weak don't-worry-nothing-happened smile.[11]

"No, that's what he told the warden". Pell offered another amused smile. "Why don't you talk to him about it? You've got sharp eyes, Officer Dance. I've seen them looking me over, deciding if I'm being straight with you. I'll bet you could tell in a flash that that boy was lying" [8].

Kipiani yerində dikəldi. Təəccüblə Әhmədin üzünə baxd1. O çox sakit idi. Lakin onun son sözü bir az bundan əvvəl dedikləri ilə düz gəlmirdi.

- Niyə təəccüb edirsən? - deyə Әhməd dostunun çiynini qucaqladi.

- Məgər sənin dərs verdiyin uşaqlar bir ordu deyilmi? Aleksey Osipoviç kəndbəkənd, şəhərbəşəhər gəzib ordu toplamırmı? Mənim gətirdiyim ayaqyalın, yamaqlı uşaqlar həmin ordunun əsgərləri olmayacaqlarmı? Niyə susursan? Məgər bunlar gələcəkdə böyük bir maarif ordusu olmayacaqmı? [10, p. 336]. The abovementioned examples "Why not?" "Why don't you talk to him about it?" və "Məgər sənin dərs verdiyin uşaqlar bir ordu deyilmi? Aleksey Osipoviç kəndbəkənd, şəhərbəşəhər gəzib ordu toplamırmı? Mənim gətirdiyim ayaqyalın, yamaqlı uşaqlar həmin ordunun əsgərləri olmayacaqlarmı? Niyə susursan? Məgər bunlar gələcəkdə böyük bir maarif ordusu olmayacaqmı?" have a leading emosional confirmation role

6. Surprise, amazement; How could people live like this? How could a country function in these conditions? How could so much air possibly reach such a temperature without heating up the entire planet? [11].
An instant later an alarm brayed, painful to the ears. "The hell's going on?"[11].

Examples in the Azerbaijani language

Ohməd məhəccərin üstündən boylana-boylana:

- Ot tayaları yanır, - dedi.

- Ogurluğa gələn otu niyə yandırır?

Ohməd məhəccərin üstündən aşağı endi.

- Bu oğru işinə oxşamır. Deyəsən ,düşmənçilik məsələsidir [10, p. 129].

In the given examples ("How could people live like this? How could a country function in these conditions? How could so much air possibly reach such a temperature without heating up the entire planet?", "The hell's going on?", "Ogurluğa gələn otu niyə yandırır?") Surprise and astonishment are easily distinguished in the pragmatics of direct speech acts.

7. Surprise, doubt; But, wait, Pell thought. It was a second alarm-the first had sounded before the explosions outside. Had someone figured out what he was going to do?

Kipiani də eyni ilə bu cür düşünür, Ohmədi gözaltı süzüb, söhbətihardan başlayacağını müəyyənləşdirirdi. Onun deməyə sözü çox idi. O bilmək istəyirdi ki, Әhməd təkdirmi, keçmiş yoldaşlarından kiminlə əlaqəsi var? Yenə əvvəlki əqidəsindədirmi? Yoxsa gənclik xəyallarından uzaqlaşmışdır? [10, p. 334].

In the given examples, surprise and doubt are intertwined; in such examples, sometimes surprises can completely overcome doubt, but the semantics of doubt retain its function depending on the communicative need.

8. Denial-confession; Q1z gözlərini yerdən ayırmadan dinməzcə onunla görüşdü. İmran başdanayağa q1zı süzdü. Zeynəb xeyli dəyişib gözəlləşmişdi. İmran Zeynəbi uşaqlıqdan tanıyırdı. O, məktəbdə həmişə dəcəllik etməyi, kiçik bir bəhanə tapıb adamlara sataşmağı, müsahibinin utandığını, yaxud da azacıq tutulduğunu görəndə şıltaqlıq edərək, gülməyi çox sevərdi. İmranın özü də çox zaman onun zarafatına dözə bilməyib qaş-qabağını sallardı. Bunu görən Zeynəb: "İmran, sən allah, həmişə belə dur, qaşqabaqlı olmaq sənə yaman yaraşır, onda mənim səndən daha çox xoşum gəlir" deyər və gülməyini güclə saxlayardi. İmran daha da əsəbiləşib:

- Sən bu xasiyyətindən nə vaxt əl çəkəcəksən? - deyərdi. Zeynəb şıltaq uşaq ədası ilə: - Allab verən xasiyyəti dəyişmək olarmı? - deyərdi. Çox vaxt də İmranın anası Tükəzban xala söhbətə qarışard1 [10].

Keçi kimi, hara gəldi dırmașırsan. Ayaq basmadığın yer yoxdur. Evimizin dörd tərəfində cığır salıbsan. Heç fikirləşmirsən ki, Tükəzban dul arvaddır, bir də kim onun qapısına-bacasına çəpər çəkəcək? [10, p. 33].

9. Emotional confession, affirmation İmran burnunun ucuna qədər qızardı. Zeynəb isə vəziyyətini pozmadan şaqqıldayıb gülür, sanki müsahibinin pərtliyindən həzz alırdı. İmran özünü topladı.

- Mən əvvəldən qarayam. Qara adamın nəyi qaralacaq? [10, p. 15].

10. Emotional will, denial.Toy toğlusu kimi nə düşübsən ortalığa? Sənə neçə dəfə demişəm, ağlını başına yı̆̆, get yıxıl öl bir yerdə. Hər yerə özünü soxma. Sonra peşman olarsan ha! [10, p. 27].

Observations on literary texts in both languages show that question-based direct speech acts are largely similar in Azerbaijani and English. We will suffice to point out a few points of this similarity. It is necessary to take a natural approach to the multiplicity of poly intensiveness in these units. Because human consciousness is multifaceted. 


\section{References:}

1. Серль Д.Р. Косвенные речевые акты. Новое в зарубежной лингвистике. 1986. Вып. XVII: Теория речевых актов. 151 с.

2. URL: www.studfile.net/preview/3302310/page:3/

3. Конрад Р. Вопросительные предложения как косвенные речевые акты. Новое в зарубежной лингвистике. 1986. Вып. XVI: Лингвистическая прагматика. $356 \mathrm{c}$.

4. Остин Д.Л. Слово как действие. Новое в зарубежной лингвистике. 1986. Вып. XVII. С. 22-30.

5. Серль Д.Р. Классификация иллокутивных актов. Новое в зарубежной лингвистике. 1986. Вып. XVII: Теория речевых актов. C. $170-194$.

6. Арнольд И.В. Стилистика современного английского языка (стилистика декодирования). Москва : Просвещение, 1981. 165 с.

7. Поспелова А.Г. Косвенные высказывания. Спорные вопросы английской грамматики. 1988. С. 141-153.

8. Jeffery D. The Sleeping Doll Monday. Chapter 1.

9. Məmmədquluzadə C. Osərləri. Dörd cild. IVcild. "Öndər Nəşriyyat", Bak1, 2004. 90 p.

10. İsmayıl Ş. Seçilmiş əsarləri. İki cilddə. I cild. Bakı, "Şərq-Qərb", 2005. P. $15-336$.

11. Сатклиф У. А ты попробуй (Юмористическая проза). URL: www.parallango.com/ru/author/109/

Ахмадова М. И. Моно- і поліінтенсивні особливості питального акту прямої мови англійською та азербайджанською мовами

Анотація. Сучасна лінгвістика активно працює над способами оптимізації міжособистісного спілкування. Ця проблема стояла на порядку денному практично в усі часи, але іiі широке наукове i теоретичне вивчення пов'язано iз сучасною лінгвістикою. Для цієї проблеми характерно використання мови в процесі спілкування, пошук найбільш придатних способів передати задум автора, тому що точне, вільне вираження думки - одна з особливостей оптимальної мови. У цьому сенсі тема статті актуальна. Стаття присвячена моно- і поліінтенсивності питальних прямих мовних актів в англійській та азербайджанській мовах. Цілеспрямоване розташування висловлювань, засноване на певних правилах у ситуації спілкування в суспільстві, називається «мовним актом». Основна позиція мовного акту - вплив на слухача. У цьому контексті акт мови, пропозиції та висловлювання, залежно від комунікативної потреби мовних одиниць, може бути перероблений автором, щоб надати нового комунікативного тону або значення наявній формі. Творчий підхід до думки таких видатних експертів, як Дейдра Вілсон, Ден Спербер, Джон Серл, Рассел Конрад, Джон Остін, Ірина Володимирівна Арнольд, розкриває проблеми формування питального прямого мовного акту. Говорячи про питально непрямий мовленнєвий акт в англійській $\mathrm{i}$ азербайджанській мовах, він ділиться на моно- і поліінтенсивний типи. Моноінтенсивність належить до побудови пропозиції на одній смисловій ідеї в непрямій мові. Поліінтенсивна пряма мова характеризується викладом двох-трьох ідей в одній структурі. Успішне спілкування в нашій мові забезпечує наше взаєморозуміння й охоплює дуже високий відсоток нашої мовної активності. У статті аналізуються основні особливості питального акту прямої мови і його комунікативна функція на основі фактів як англійської, так і азербайджанської мов. У результаті в статті робиться висновок про багатство функціональних значень питальних речень у тексті.

Ключові слова: текст, запитання, обробка, прямий мовний акт, речення, висловлювання, моноінтенціональність, поліінтенціональність. 